\title{
An evaluation of public understanding regarding COVID- 19 in Sindh, Pakistan: A focus on knowledge, attitudes and practices
}

\author{
Narendar KUMAR ${ }^{1, *} \mathbb{D}^{D}$, Syed Azhar Syed SULAIMAN 1,2 $\mathbb{D}$, Furqan Khurshid HASHMI ${ }^{3}$ \\ 1 Department of Clinical Pharmacy, School of Pharmaceutical Sciences, Universiti Sains Malaysia, Penang, Malaysia. \\ 2 Advanced Medical and Dental Institute, Universiti Sains Malaysia, Penang, Malaysia \\ 3 University College of Pharmacy, University of the Punjab, Lahore, Pakistan. \\ * Corresponding Author. E-mail: nkumar.bhojak@usindh.edu.pk (N.K.); Tel. +93-333-277 6593.
}

Received: 27 April 2021 / Revised: 07 July 2021/ Accepted: 13 July 2021

\begin{abstract}
Coronavirus disease-2019 (COVID-19) has emerged as a global crisis. Inadequate knowledge, inapt attitude, and malpractice may enhance the risk of disease. Therefore, we aimed to explore the knowledge and behaviors of the people towards COVID-19 in Sindh, Pakistan, that can further help the government to enforce the SOPs for better containment strategy. A cross sectional study was conducted in Sindh, Pakistan during the month of December, 2020 using convenience sampling method. A pre-designed and pre-validated online survey consisting of 30 questions on knowledge, attitude and practice (KAP) regarding COVID-19 was used for data collection. Among 1004 respondents, accuracy of knowledge response ranged from $20.7 \%$ to $95.2 \%$ and average rate was $62.2 \%$. For attitude, the percentage of positive responses ranged from $16.9 \%$ to $49.5 \%$ and average value was $34.88 \%$. The range for good practice was $15.0 \%$ to $91.4 \%$ and the average was $67.4 \%$. The statistical analysis results showed the significant differences between the responses of each participant for knowledge, attitude, and practices towards COVID-19 (P = 0.001). Our study concluded that majority of people of Sindh, Pakistan have good knowledge, average attitude, and proactive practices regarding COVID-19 but still there is a need for implementing strategies for enhancing knowledge and practices.
\end{abstract}

KEYWORDS: COVID-19; knowledge; attitude; practice; Sindh.

\section{INTRODUCTION}

Coronavirus disease 2019 (COVID -19) has emerged as a global crisis that is caused by the severe acute respiratory syndrome coronavirus 2 (SARS-CoV-2). It was detected for the first time in Wuhan, China in December 2019 [1, 2]. Due to its rapid and global spread, the World Health Organization (WHO) declared the outbreak as a pandemic by March 11, 2020 [3]. In Pakistan, the first COVID-19 case was confirmed in Karachi (Capital of Sindh) on February 26, 2020 [4]. It is a respiratory illness and is characterized by sometimes asymptomatic to symptomatic nature that ranges from mild symptoms like fever, fatigue, dry cough, sore throat, and myalgia to pneumonia and acute respiratory distress syndrome (ARDS) in severe cases [5]. As of January 29, 2021, a total of 101,053,721 confirmed cases have been identified globally and the death toll reached to 2,182,867 [6]. There have been 539,387 confirmed cases in Pakistan with 11,514 deaths. However, province Sindh has recorded more than 245,663 cases therefore, is the most highly affected province in the country [7].

The Director-General of WHO expressed that our fight is not only against pandemic but also with the surge of information coining a new term in the context of widespread infection as infodemic [8]. Besides the massive information regarding the virus is being disseminated through different print and electronic media, a flood of misinformation is also easily propagating through these sources [9]. Moreover, misperception regarding the methods of curbing transmission and viral exposure among the public has potentiated the risk of infection [10]. The war against COVID-19 is ongoing in the world including Pakistan. However, the public's adherence to Standard Operating Procedures (SOPs) is an essential component to curtail the spread of disease which is highly inclined by their knowledge, attitude, and practices concerning COVID-19 [11, 12]. Insufficient knowledge, inappropriate attitude, and malpractice may enhance the risk of disease [13]. and

How to cite this article: Kumar N, Sulaiman SAS, Hashmi FK. An evaluation of public understanding regarding COVID-19 in Sindh, Pakistan: A focus on knowledge, attitudes and practices. J Res Pharm. 2021; 25(6): 881-889. 
understanding of the people may help to forecast the results of strategic behavior. Therefore, this study was conducted with the aim to explore the knowledge and behaviors of the people towards COVID-19 in Sindh Province, Pakistan, that can further help the government to enforce the SOPs for better containment strategy.

\section{RESULTS}

\subsection{Participant characteristics}

A total of 1004 responses from various cities of Sindh were recorded through this online survey. Approximately $2 / 3^{\text {rd }}$ of the respondents were male $(64.7 \%)$ and falling in the age group $18-27$ years $(64.2 \%)$. More than half $(62 \%)$ were holding a bachelor's degree and $43.1 \%$ were students followed by private employees $(32.5 \%)$ and belonging to an urban areas $(67.3 \%)$. More than one-third of respondents $(36.7 \%)$ were having a monthly income of 10,000 to 50,000 PKR. Participants' characteristics details are described in Table 1.

Table 1. Demographic and socio-economic characteristics of the study population $(\mathrm{N}=1004)$.

\begin{tabular}{lc}
\hline Participants Characteristics & $\mathbf{N}(\mathbf{0})$ \\
\hline Gender & \\
Female & $354(35.3)$ \\
Male & $650(64.7)$ \\
Age (yrs) & \\
18-27 & $645(64.2)$ \\
$28-37$ & $280(27.8)$ \\
$38-47$ & $52(5.1)$ \\
$48-57$ & $20(1.9)$ \\
58 and above & 7 \\
Education & $(0.6)$ \\
Primary & $3(0.3)$ \\
Matriculation & $12(1.2)$ \\
Intermediate & $67(6.7)$ \\
Diploma & $7(0.7)$ \\
Bachelors & $622(62.0)$ \\
Masters & $246(24.6)$ \\
Doctorate & $47(4.7)$ \\
Profession & \\
Student & $433(43.1)$ \\
Govt. Job & $175(17.4)$ \\
Private job & $326(32.5)$ \\
Personal business & $58(5.8)$ \\
Retired & $2(0.2)$ \\
Daily wager & $10(1.0)$ \\
Income & \\
Under Rs. 10000 & $56(5.6)$ \\
Rs. 11000-50000 & $368(36.7)$ \\
Rs. 51000-100000 & $173(17.3)$ \\
Rs. 101000 and above & $98(9.8)$ \\
No response & $309(30.8)$ \\
Locality & \\
Rural & $328(32.7)$ \\
Urban & $676(67.3)$ \\
\hline
\end{tabular}

\subsection{Participants' knowledge towards COVID-19}

The assessment of accurate knowledge response ranged from 20.7\% (Animals are the source of transmission of COVID-19) to $95.2 \%$ (COVID-19 has very badly affected the educational system), and the average rate of accuracy was $62.2 \%$. A major proportion of respondents $(92.6 \%)$ agreed that social interactions (handshaking/hugging/public gatherings) may spread the infection among the public and $90.6 \%$ believed that frequent hand sanitizing/washing practices can decrease the spread of COVID-19. The distribution of accuracy of knowledge is summarized in Table 2. 
Table 2. Participants' knowledge regarding COVID-19 (N=1004).

\begin{tabular}{|c|c|c|}
\hline & Knowledge Items & $\begin{array}{l}\text { Accuracy } \\
\text { N (\%) }\end{array}$ \\
\hline K1. & $\begin{array}{l}\text { The major symptoms of COVID-19 are fever, body aches, shortness of breath, } \\
\text { dry cough. }\end{array}$ & $822(81.9)$ \\
\hline K2. & $\begin{array}{l}\text { Runny nose, sneezing, nasal irritation, facial pain is uncommon among patients } \\
\text { with COVID-19. }\end{array}$ & $483(48.1)$ \\
\hline K3. & Is there any treatment available for COVID-19? & $228(22.7)$ \\
\hline K4. & Does all age groups are affected similarly due to COVID-19? & $403(40.1)$ \\
\hline K5. & Animals are the source of transmission of COVID-19. & $208(20.7)$ \\
\hline K6. & Asymptomatic positive COVID-19 patient can transmit the infection to others. & $809(80.6)$ \\
\hline K7. & Local transmission occurs due to respiratory droplets. & $755(75.2)$ \\
\hline K8. & Does COVID- 19 is an airborne infection? & $494(49.2)$ \\
\hline K9. & Is it necessary for everyone to wear a mask everywhere? & $863(86)$ \\
\hline K10. & $\begin{array}{l}\text { Does COVID-19 spread through handshaking/hugging/large public } \\
\text { gatherings? }\end{array}$ & $930(92.6)$ \\
\hline K11. & Frequent hand washing practices are necessary to decrease transmission? & 909 (90.5) \\
\hline K12. & Is it necessary to use hand sanitizers only? & $407(40.5)$ \\
\hline K13. & Does isolation facility is available in your city? & $598(59.6)$ \\
\hline K14. & $\begin{array}{l}\text { Does every person with positive COVID-19 test should go to isolation center } \\
\text { for } 14 \text { days? }\end{array}$ & $790(78.7)$ \\
\hline K15. & Does everyone should be tested for COVID-19 in the community? & $585(58.3)$ \\
\hline K16. & $\begin{array}{l}\text { Is mortality rate of COVID-19 more than other chronic diseases like TB, } \\
\text { Hepatitis? }\end{array}$ & $463(46.1)$ \\
\hline K17. & Does lockdown is the only solution to decrease the transmission of COVID-19? & 267 (26.6) \\
\hline K18. & Does second wave of COVID-19 is more dangerous than the first? & 599 (59.7) \\
\hline K19. & $\begin{array}{l}\text { Do you think that COVID-19 has brought up huge economic crisis in the } \\
\text { country? }\end{array}$ & $918(91.4)$ \\
\hline K20. & Do you think that COVID-19 has very badly affected the educational system? & $956(95.2)$ \\
\hline
\end{tabular}

\subsection{Participants' attitude towards COVID-19}

The assessment of participants' attitudes related to COVID-19 is presented in Table 3. The average response rate for a positive attitude was $34.88 \%$. Approximately half of participants (49.5\%) had a positive attitude for A1 as shown in Table 3. The male participants' attitude was comparatively more positive than females $(p=0.034)$. However, there wasn't any significant difference of attitude among other variables except education $(\mathrm{p}=0.001)$ as described in Table 5 .

Table 3. Participants' attitude regarding COVID-19 (N=1004).

\begin{tabular}{|c|c|c|c|}
\hline Participants Attitude & $\begin{array}{c}\text { Positive } \\
\text { Attitude } \\
\text { N (\%) }\end{array}$ & $\begin{array}{c}\text { Neutral } \\
\text { Attitude } \\
\text { N (\%) }\end{array}$ & $\begin{array}{c}\text { Negative } \\
\text { Attitude } \\
\mathbf{N}(\%)\end{array}$ \\
\hline A1. Are you afraid of COVID-19? & $497(49.5)$ & $91(9.1)$ & $416(41.4)$ \\
\hline $\begin{array}{l}\text { A2. Do hospitals are effectively treating serious } \\
\text { COVID-19 patients? }\end{array}$ & 408 (40.6) & $226(22.5)$ & $370(36.9)$ \\
\hline $\begin{array}{l}\text { A3. Do you think that Pakistan is controlling COVID- } \\
19 \text { very efficiently? }\end{array}$ & $333(33.2)$ & $237(23.6)$ & $434(43.2)$ \\
\hline $\begin{array}{l}\text { A4. Do you think Pakistan will be successful in } \\
\text { treating COVID-19 completely? }\end{array}$ & $343(34.2)$ & $332(33.1)$ & $329(32.8)$ \\
\hline $\begin{array}{l}\text { A5. Do you think that vaccine will be available by the } \\
\text { end of } 2020 \text { for common use? }\end{array}$ & $170(16.9)$ & $316(31.5)$ & $518(51.6)$ \\
\hline
\end{tabular}

\subsection{Participants' practices towards COVID-19}

The evaluation of good practices to control COVID-19 was based on 5 questions. The average of good practices among participants was $67.4 \%$. However, percentages of good practices for P1 to P4 were more than $70 \%$ as shown in Table 4 . The use of face masks was adopted by a majority of participants (91.4\%). While $85.4 \%$ of participants reported that they adopted hand hygiene practices. The statistical analysis showed the significant difference among different groups for education $(p=0.012)$ as shown in Table 6 .

\subsection{Comparison of KAP scores among different variables.}

Among all respondents, the average score for Knowledge was 12.4 \pm 3.1 (range: 0 20), Attitude 4.6 \pm 2.5 (range: $0 \sim 10$ ), and Practice $7.1 \pm 2.1$ (range: $0 \sim 10$ ). The statistical analysis results showed the significant 
differences between the responses of each participant for knowledge, attitude, and practices towards COVID-19 $(\mathrm{P}=0.001)$ as described in Table 5 .

Table 4. Participants practices regarding COVID-19 (N=1004).

\begin{tabular}{lccc}
\hline Participants' Practices & $\begin{array}{c}\text { Good } \\
\text { Practices } \\
\mathbf{N}(\%)\end{array}$ & $\begin{array}{c}\text { Neutral } \\
\text { Practices } \\
\mathbf{N}(\%)\end{array}$ & $\begin{array}{c}\text { Poor } \\
\text { Practices } \\
\text { N (\%) }\end{array}$ \\
\hline $\begin{array}{l}\text { P1. Do you avoid attending crowded gathering } \\
\text { nowadays? }\end{array}$ & $707(70.4)$ & $63(6.3)$ & $234(23.3)$ \\
$\begin{array}{l}\text { P2. Do you wear mask while going to crowded } \\
\text { places? }\end{array}$ & $918(91.4)$ & $26(2.6)$ & $60(6.0)$ \\
$\begin{array}{l}\text { P3. Do you follow social distancing practices while } \\
\text { meeting others? }\end{array}$ & $750(74.7)$ & $72(7.2)$ & $182(18.1)$ \\
$\begin{array}{l}\text { P4. Do you adopt proper hand washing /hand } \\
\text { sanitizing techniques? }\end{array}$ & $857(85.4)$ & $54(5.4)$ & $93(9.3)$ \\
P5. Do you think people completely follow SOPs? & $151(15.0)$ & $84(8.4)$ & $769(76.6)$ \\
\hline
\end{tabular}

Table 5. Descriptive and inferential analysis of all study components.

\begin{tabular}{|c|c|c|c|c|c|c|c|c|}
\hline \multirow{2}{*}{$\begin{array}{l}\text { Study } \\
\text { components }\end{array}$} & \multicolumn{8}{|c|}{ Descriptive and inferential statistics $(\mathrm{P}<0.05)$} \\
\hline & $\mathbf{N}$ & Maximum score & Min & $\operatorname{Max}$ & Sum & Mean & $\begin{array}{c}\text { Std. } \\
\text { Deviation }\end{array}$ & P-value \\
\hline $\begin{array}{l}\text { Knowledge } \\
\text { Score }\end{array}$ & 1004 & 20 & 0 & 20 & 12489.00 & 12.4392 & 3.05863 & 0.001 \\
\hline Attitude Score & 1004 & 10 & 0 & 10 & 4704.00 & 4.6853 & 2.52693 & 0.001 \\
\hline Practices Score & 1004 & 10 & 0 & 10 & 7065.00 & 7.0369 & 2.08437 & 0.001 \\
\hline
\end{tabular}

Table 6 shows the average scores for each component with respect to different characteristics related to study participants. The statistical analysis results indicated the significant differences between the responses of each participant related to knowledge towards COVID-19 with respect to gender, age, education, and profession of participants. In addition, significant differences were also observed in attitude scores with respect to gender and education while significant differences in the practice scores were also found with respect to the education of the participants.

Figure 1 shows the percentage scores of participants calculated from their total maximum scores for knowledge, positive attitude, and practices towards COVID-19 while Figure 2 presents the percentage scores of participants with respect to gender calculated from their total maximum scores for knowledge, positive attitude, and practices towards COVID-19.

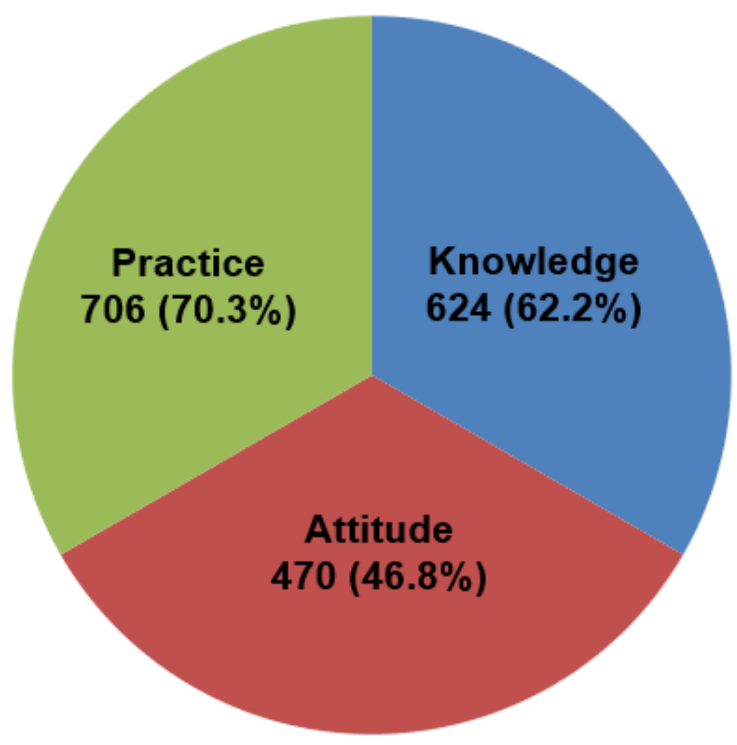

Figure 1. Percentage scores of participants calculated from their total maximum scores for accurate knowledge, positive attitude and good practices towards COVID-19 (N=1004). 
Table 6. Inferential analysis of all study components with respect to participant's characteristics.

\begin{tabular}{|c|c|c|c|c|c|c|}
\hline \multirow{3}{*}{ Factors } & \multicolumn{6}{|c|}{ Study Components } \\
\hline & \multicolumn{2}{|c|}{ Knowledge } & \multicolumn{2}{|c|}{ Attitude } & \multicolumn{2}{|c|}{ Practice } \\
\hline & $\begin{array}{c}\text { Average } \\
\text { scores }\end{array}$ & P-values & $\begin{array}{c}\text { Average } \\
\text { scores }\end{array}$ & P-values & $\begin{array}{c}\text { Average } \\
\text { scores }\end{array}$ & P-values \\
\hline \multicolumn{7}{|l|}{ Gender } \\
\hline Male & $12.93 \pm 2.23$ & \multirow{3}{*}{0.027} & $4.60 \pm 0.92$ & \multirow{3}{*}{0.034} & $6.93 \pm 1.51$ & \multirow{3}{*}{0.105} \\
\hline Female & $12.16 \pm 2.16$ & & $4.82 \pm 0.83$ & & $7.22 \pm 2.03$ & \\
\hline Total & $12.43 \pm 1.35$ & & $4.68 \pm 0.91$ & & $7.03 \pm 2.13$ & \\
\hline \multicolumn{7}{|l|}{ Age } \\
\hline $18-27 y$ & $12.59 \pm 2.63$ & \multirow{5}{*}{0.021} & $4.79 \pm 1.03$ & \multirow{5}{*}{0.451} & $7.05 \pm 1.94$ & \multirow{5}{*}{0.070} \\
\hline $28-37 y$ & $12.29 \pm 1.82$ & & $4.46 \pm 0.68$ & & $7.00 \pm 1.53$ & \\
\hline $38-47 y$ & $11.73 \pm 2.15$ & & $4.82 \pm 0.99$ & & $7.25 \pm 1.72$ & \\
\hline $48-57 y$ & $11.85 \pm 1.81$ & & $4.05 \pm 1.02$ & & $6.65 \pm 1.23$ & \\
\hline$\geq 58 y$ & $11.28 \pm 3.23$ & & $4.42 \pm 0.97$ & & $6.14 \pm 1.81$ & \\
\hline \multicolumn{7}{|l|}{ Education } \\
\hline Primary & $12.66 \pm 2.13$ & \multirow{7}{*}{0.003} & $4.33 \pm 1.01$ & \multirow{7}{*}{0.001} & $5.33 \pm 1.33$ & \multirow{7}{*}{0.012} \\
\hline Matriculation & $11.75 \pm 3.05$ & & $6.25 \pm 1.23$ & & $5.75 \pm 1.71$ & \\
\hline Intermediate & $11.65 \pm 2.24$ & & $5.67 \pm 1.15$ & & $7.28 \pm 1.22$ & \\
\hline Diploma & $16.00 \pm 3.13$ & & $4.42 \pm 0.93$ & & $7.71 \pm 1.13$ & \\
\hline Bachelors & $12.45 \pm 2.95$ & & $4.68 \pm 0.87$ & & $7.02 \pm 1.23$ & \\
\hline Masters & $12.39 \pm 2.93$ & & $4.50 \pm 0.94$ & & $7.03 \pm 1.11$ & \\
\hline Doctorate & $13.25 \pm 2.20$ & & $3.93 \pm 0.99$ & & $7.14 \pm 2.09$ & \\
\hline \multicolumn{7}{|l|}{ Profession } \\
\hline Student & $12.53 \pm 2.29$ & \multirow{6}{*}{0.000} & $4.79 \pm 0.98$ & \multirow{6}{*}{0.209} & $6.97 \pm 1.95$ & \multirow{6}{*}{0.073} \\
\hline Govt. Job & $12.26 \pm 2.18$ & & $4.62 \pm 1.01$ & & $7.12 \pm 1.91$ & \\
\hline Private job & $12.66 \pm 2.55$ & & $4.54 \pm 1.23$ & & $7.16 \pm 1.88$ & \\
\hline Personal & $11.51 \pm 2.13$ & & $4.75 \pm 0.92$ & & $6.77 \pm 1.70$ & \\
\hline business & $12.50 \pm 1.94$ & & $3.00 \pm 0.79$ & & $8.00 \pm 1.81$ & \\
\hline $\begin{array}{l}\text { Retired } \\
\text { Daily wager }\end{array}$ & $9.30 \pm 1.07$ & & $5.50 \pm 1.03$ & & $5.40 \pm 1.01$ & \\
\hline \multicolumn{7}{|l|}{ Locality } \\
\hline Rural & $12.29 \pm 2.75$ & 0.180 & $4.85 \pm 0.83$ & 0.198 & $7.26 \pm 1.91$ & 0.053 \\
\hline Urban & $12.50 \pm 2.93$ & & $4.60 \pm 0.91$ & & $6.92 \pm 1.43$ & \\
\hline
\end{tabular}

$\mathrm{N}=1004, *(\mathrm{P}=0.05),{ }^{* *}$ Mean $\pm \mathrm{SD}$

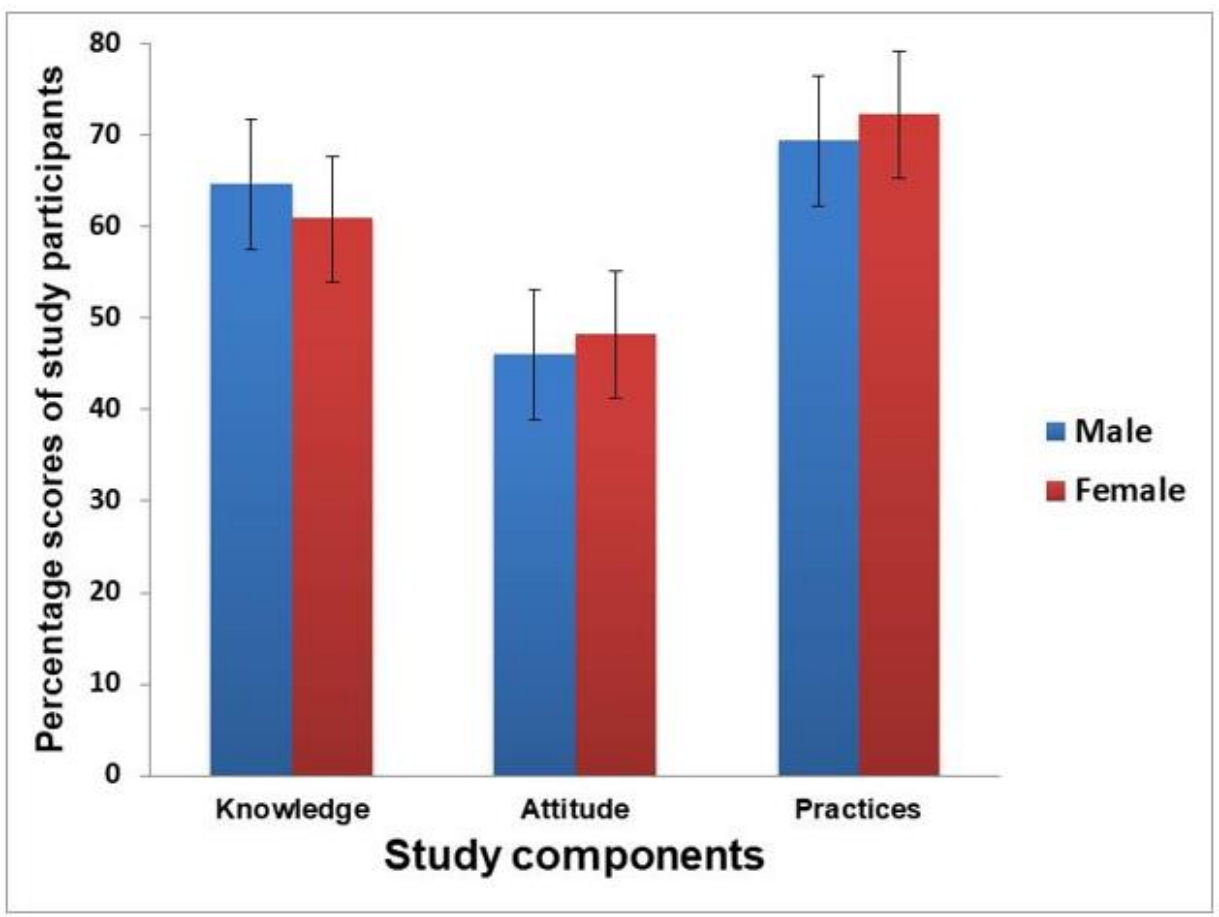

Figure 2. Percentage scores of participants with respect to gender calculated from their total maximum scores for knowledge, positive attitude and practices towards COVID-19 ( $\mathrm{N}=1004)$. 


\section{DISCUSSION}

The present study was conducted to evaluate the level of knowledge, attitude, and practices regarding COVID-19 among the people in Sindh, Pakistan as Sindh has recorded the highest number of positive cases in the country [4]. This assessment was crucial to enhance preventive measures against COVID-19 in the general population as there is no particular treatment or vaccine available for common use. The provincial government has imposed partial lockdowns, ordered to reduce staff at workplaces, assuring to adopt SOPs by the public as directions issued by National Command Operation Centre (NCOC) [14]. In addition, present circumstances are not favorable as people are not following SOPs properly and a number of cases are rapidly getting escalated. The outcomes reveal a considerable number of demographic factors associated with knowledge, attitude, and practice and will be helpful for health authorities to plan educational awareness on such pandemics. The current study revealed the mean score of knowledge, attitude, and practice as $12.43 \pm$ 3.05 (out of 20 ), $4.68 \pm 2.52$ (out of 10 ), and $7.03 \pm 2.08$ (out of 10 ) respectively.

This cross-sectional survey showed that the average accuracy rate about knowledge was $62.2 \%$, suggesting a mediocre level of knowledge. The similar rate of accuracy has been reported in a Chinese study where the overall correct rates of knowledge items were 61.9\% [15]. Consistent with our findings a study from India revealed a moderate level of awareness of COVID-19 among the public with respect to the mode of transmission, symptoms, and adequate precautionary measures [16]. The majority of participants in our study agreed that social interactions such as; handshaking, hugging, and public gatherings may spread the infection among people. In line with our study, a survey from Pakistan reported that $85.1 \%$ and $69.2 \%$ thought social gatherings and handshaking a common reason for the transmission of diseases [17]. Consistent with the previous study [18] from Pakistan, the current study also explored that the average knowledge score was considerably higher among males than females. However, few studies from Bangladesh by Sultana et al [19] and Pakistan by Iqbal and Younas [20] disclosed a high level of knowledge and awareness among females in contrast to males. Furthermore, it was observed that the average knowledge score was high among participants aged 18 to 37 years with the diploma and doctorate level of education. However, in a previously published study by Iqbal and Younas [21] the knowledge score was highest among participants with age above 40 years and those who were of doctorate level or enrolled. Moreover, knowledge was found to be high among participants from urban Sindh in contrast to rural Sindh although there was a non-significant relationship. This could be due to the limited access to smartphones and internet as well as a low literacy rate in rural Sindh.

The attitude and behavior of the public towards the COVID-19 pandemic play a vital role in its spread. According to our findings, the average response rate for a positive attitude was $34.88 \%$. Similarly, an inferential analysis revealed a relationship between positive attitude with the level of education and gender. There was a significantly high attitude score among female participants as compared to males which are concordant to the findings of Afzal et al [18]. Consistent with the previous study [21] from Pakistan, it was observed that there was a significant association between age and education. It was observed that a high attitude score was found among participants who were of matric and intermediate level in education.

Our study demonstrated that the average of good practices in following precautionary measures among participants was $67.4 \%$. However, Saqlain et al have reported $80 \%$ of participants with positive practices in Pakistan [21]. Among various preventive practices employed, wearing masks were found to be the most popular $(91.4 \%)$, followed by hand washing, and sanitizing practice $(85.4 \%)$. This is in line with a survey conducted in Karachi, Pakistan [22]. Furthermore, it was observed that the average score of practices was significantly high (greater than 7.0 out of 10) among participants aged 18 to 47 years. Similarly, a greater than 7 average scores of practices was significantly related with education such as; intermediate, diploma, bachelors, masters, and doctorate level. This is in consistent with previously published studies [21, 23] which indicated the association of a lower level of education such as; matriculation with poor practices. Moreover, there was high practice score among the rural participants of Sindh as compared to participants from urban Sindh.

There are several implicit limitations of our study. Firstly, as it is an online study, the response depends primarily on honesty and partly on the ability to recall. Therefore, it may be subjected to bias recall. Secondly, due to online surveys, the study by virtue of its nature excludes the part of society that do not have access to technology. Thirdly, the study was limited only to province Sindh and the sample size was not larger enough to generalize the findings of the study. Fourthly, the potential sample clustering, as most participants were young and students, may also limit the generalizability of the study. 


\section{CONCLUSION}

Our study concluded that people of Sindh, Pakistan have good knowledge, average attitude, and proactive practices regarding COVID-19. The study reflected a higher level of knowledge regarding the symptoms, route of transmission, preventive measure and impact of COVID-19 pandemic on country's economic and education system. Our findings also suggested that female participants had comparatively less knowledge, more positive attitude and adopted proactive practices than male participants. Although people are conscious about COVID-19, there is a need to take aggressive steps to improve knowledge and implement best practices to an adequate level. The findings of the study may also assist policymakers to identify and target the vulnerable population for precautionary measures and to provide health education regarding COVID-19.

\section{MATERIALS AND METHODS}

\subsection{Study design and sampling}

This online cross-sectional study was conducted during the second wave of COVID-19 in Sindh Province, Pakistan using the convenience sampling method during the month of December, 2020. The questionnaire was developed using WHO guidelines on prevention and control measures for COVID-19 [24] and general guidelines for COVID-19 recommended by the Government of Pakistan [25]. The online link of Google form was shared with prospective respondents on Facebook and Whatsapp. The reliability of the survey form was established by testing a pilot study for 50 participants yielding a Chronbach Alpha value of 0.746 . The responses of the pilot study were excluded from the final results. Respondents who were able to understand English and were aged 18 years and above having internet facilities were recruited across Sindh Province, Pakistan for the study.

\subsection{Measures}

The online questionnaire contained a general statement about background, purpose, voluntary participation, declarations of confidentiality, and questions regarding knowledge, attitude, and practices about COVID-19. The survey questionnaire consisted of 7 questions on demographic characteristics including; gender, age, education, profession, monthly income, residential area, district. A total of 30 questions were about knowledge, attitude, and practices with options as Yes, No and Maybe.

\subsection{Knowledge}

The knowledge portion consisted of 20 questions related to the clinical presentation of the disease, availability of treatment, affected age groups, mode of transmission, mortality rate, intensity, precautionary measure, isolation facility, the impact of the disease on society, and possible solution. Each correct option was allotted 1 point and wrong or maybe option 0 points.

\subsection{Attitude}

The attitude of respondents was measured by 5 questions based on the perceptions of the respondents regarding psychological fear, control, the treatment facility in hospitals, and availability of vaccine. The answer to each question had 3 directions; 2 points for a positive attitude, 1 point for neutral, and 0 points for negative.

\subsection{Practice}

The practice of respondents was assessed by 5 questions related to the behavior of going to mass gatherings, using face masks, frequent hand washing/sanitizing, and following standard operating procedures (SOPs). The answers were assigned as "Good Practice (2 points)", "Neutral Practices (1 point)" and "Poor Practice (0 points)".

\subsection{Statistical analysis}

The results were presented in percentages and mean \pm standard deviation $(X \pm S . D)$. Non-Parametric tests were applied to estimate the significance of the study using SPSS (version 23). Wilcoxon signedrank test and chi-square test were used to assess the significance of data among different variables. Finally, the data were compared and analyzed at a significance level of 0.05 . 
Acknowledgements: The authors are very thankful to all study participants for their cooperation in sparing time to fill-out the questionnaires. The authors are also thankful to Universiti Sains Malaysia for their support. The authors are grateful to Ethical Committee, Faculty of Pharmacy, University of Sindh, Jamshoro, Pakistan.

Author contributions: Concept - N.K., S.A..; Design - B.Y., N.K., S.A.; Supervision - S.A., F.H.; Resources - N.K., F.H.; Materials - N.K..; Data Collection and/or Processing - N.K.,; Analysis and/or Interpretation - N.K., F.H.; Literature Search - B.Y., N.K..; Writing - N.K.; Critical Reviews - N.K., S.A., F.H.

Conflict of interest statement: There is no conflict of interest among the authors.

Ethical consideration: The online survey study was approved by Ethical Committee, Faculty of Pharmacy, University of Sindh, Jamshoro, Pakistan (Ref: No. D. Ph./2021-01).

\section{REFERENCES}

[1] Ruan S. Likelihood of survival of coronavirus disease 2019. Lancet Infect Dis. 2020; 20(6): 630-631. [CrossRef]

[2] Muhammad S, Jamali J, Ahmer A, Sultana R, Kumari G, Abbas J, Kumar N, Khaskheli MS, Tabassum R, Qureshi Y. Safety and Awareness of Healthcare Workers During the COVID-19 Outbreak; A Cross-Sectional Study. J Pharm Res Int. 2021; 32(38): 30-38. [CrossRef]

[3] Sohrabi C, Alsafi Z, O'Neill N, Khan M, Kerwan A, Al-Jabir A, Iosifidis C, Agha R. World Health Organization declares global emergency: A review of the 2019 novel coronavirus (COVID-19). Int J Surg. 2020; 76: 71-76. [CrossRef]

[4] Government of Pakistan, COVID-19 Situation. http://covid.gov.pk/ (accessed January 29, 2021).

[5] Pravash B, Dhan Bahadur S, Sitaram K, Santoshi G. COVID-19 Status in Nepal and the Way Forward. Europasian J Med Sci. 2020; 2(2): 24-29. [CrossRef]

[6] WHO Coronavirus Disease (COVID-19) Dashboard. https://covid19.who.int. (accessed January 29, 2021)

[7] WHO. Pakistan COVID-19 situation reports. http://www.emro.who.int/pak/information-resources/pakistancovid-19-situation-reports.html (accessed January 29, 2021)

[8] WHO Munich Security Conference. https://www.who.int/dg/speeches/detail/munich-security-confer-ence. (accessed January 29, 2021).

[9] Depoux A, Martin S, Karafillakis E, Preet R, Wilder-Smith A, Larson H. The pandemic of social media panic travels faster than the COVID-19 outbreak. J Travel Med. 2020: 27(3): taaa031. [CrossRef]

[10] Bedford J, Enria D, Giesecke J, Heymann DL, Ihekweazu C, Kobinger G, Lane HC, Memish Z, Oh M-d, Schuchat A. COVID-19: towards controlling of a pandemic. Lancet. 2020; 395(10229): 1015-1018. [CrossRef]

[11] Ajilore K, Atakiti I, Onyenankeya K. College students' knowledge, attitudes and adherence to public service announcements on Ebola in Nigeria: Suggestions for improving future Ebola prevention education programmes. Health Educ J. 2017; 76(6): 648-660. [CrossRef]

[12] Tachfouti N, Slama K, Berraho M, Nejjari C. The impact of knowledge and attitudes on adherence to tuberculosis treatment: a case-control study in a Moroccan region. Pan Afr Med J. 2012; 12(1). [CrossRef]

[13] McEachan R, Taylor N, Harrison R, Lawton R, Gardner P, Conner M. Meta-analysis of the reasoned action approach (RAA) to understanding health behaviors. Ann Behav Med. 2016; 50(4): 592-612. [CrossRef]

[14] Government of Pakistan. National Command Operation Center. Initiatives https://ncoc.gov.pk/govtinitiatives.php (accessd December 21, 2020).

[15] Yue S, Zhang J, Cao M, Chen B. Knowledge, attitudes and practices of COVID-19 among urban and rural residents in China: a cross-sectional study. J Community Health. 2021; 46(2): 286-291. [CrossRef]

[16] Roy D, Tripathy S, Kar SK, Sharma N, Verma SK, Kaushal V. Study of knowledge, attitude, anxiety \& perceived mental healthcare need in Indian population during COVID-19 pandemic. Asian J Psychiatr. 2020: 102083. [CrossRef]

[17] Mahmood S, Hussain T, Mahmood F, Ahmad M, Majeed A, Beg BM, Areej S. Attitude, Perception, and Knowledge of COVID-19 Among General Public in Pakistan. Front Public Health. 2020; 8: 861. [CrossRef]

[18] Afzal MS, Khan A, Qureshi UUR, Saleem S, Saqib MAN, Shabbir RMK, Naveed M, Jabbar M, Zahoor S, Ahmed H. Community-based assessment of knowledge, attitude, practices and risk factors regarding COVID-19 among Pakistanis residents during a recent outbreak: a cross-sectional survey. J Community Health. 2021; 46(3): 476486[CrossRef] 
[19] Sultana MS, Khan AH, Islam MR, Hossain S, Hasan MT, Kurasaki M, Sikder MT. Gender differences in Knowledge, Attitude and Preparedness to Respond to COVID-19 among adult population in Bangladesh: A Cross-sectional Study. Preprints 2020. 2020110739. [CrossRef]

[20] Iqbal MA, Younas MZ. Public knowledge, attitudes, and practices towards COVID-19 in Pakistan: A cross-sectional study. Children and Youth Services Review. 2020; 120: 105784. [CrossRef]

[21] Saqlain M, Ahmed A, Gulzar A, Naz S, Munir MM, Ahmed Z, Kamran S. Public Knowledge and Practices regarding COVID-19: A cross-sectional survey from Pakistan. Front Public Health. 2021; 9: 629015. [CrossRef]

[22] Jawed F, Manazir S, Zehra A, Riaz R. The novel Coronavirus disease (COVID-19) pandemic: Knowledge, attitude, practice, and perceived stress among health care workers in Karachi, Pakistan. Med J Islam Repub Iran. 2020; 34: 132. [CrossRef]

[23] Hayat K, Rosenthal M, Xu S, Arshed M, Li P, Zhai P, Desalegn GK, Fang Y. View of Pakistani residents toward coronavirus disease (COVID-19) during a rapid outbreak: a rapid online survey. Int J Env Res Pub He. 2020; 17(10): 3347. [CrossRef]

[24] WHO. Coronavirus disease (COVID-19) advice for the public: Mythbusters. https://www.who.int/emergencies/diseases/novel-coronavirus-2019/advice-for-public/myth-busters. (accessed December 22, 2020).

[25] Government of Pakistan. Guidelines. https://covid.gov.pk/guidelines. (accessed December 18, 2020).

This is an open access article which is publicly available on our journal's website under Institutional Repository at http://dspace.marmara.edu.tr. 